\title{
Uptake of Taurocholate by Hepatocytes Isolated from Developing Rats
}

\author{
FREDERICK J. SUCHY, ${ }^{(49)}$ AND WILLIAM F. BALISTRERI \\ Division of Gastroenterology and Department of Pediatrics, Children's Hospital Research Foundation, Cincinnati, \\ Ohio, USA
}

\begin{abstract}
Summary
To further define developmental changes in bile acid metabolism, we determined the kinetics of taurocholate uptake by hepatocytes isolated from Sprague-Dawley rats at 7, 14, 21, 28, and 56 days of age. There was a progressive increase in taurocholate uptake with age. The uptake process exhibited saturable kinetics in every age group with a maximum uptake velocity attained above a taurocholate concentration of $200 \mu \mathrm{M}$. There were no differences in $\mathrm{Km}$ values but Vmax increased progressively between 7 and 56 days of age. These data suggest that the deficit in hepatic excretory function observed in immature mammals of several species may, in part, be related to decreased transport of bile acids.

\section{Speculation}

Impaired transport of bile acids by the liver may limit bile flow during development and lead to inefficient fat digestion, altered hepatic excretion of drugs, and an increased susceptibility to cholestasis. Comparable $\mathrm{Km}$ values for the uptake process indicate that hepatocyte affinity for taurocholate remains constant during development; whereas the rise in Vmax with postnatal age may reflect an increase in the number of binding sites. Specific changes in the liver cell plasma membrane are likely to be important determinants of the ontogeny of bile acid transport and bile flow.
\end{abstract}

Bile acids are major synthetic and excretory products of the liver and are of primary importance in the generation of bile flow $(11,15,20)$. There is increasing evidence in humans and in experimental animals that the enterohepatic circulation of bile acids is not fully developed at birth and that the perinatal liver is normally subject to a period of "physiological cholestasis" (13, 14, $41)$. In the normal human infant and in the suckling rat, bile acid pool size is decreased $(42,44)$ and the concentration of bile acids in serum is elevated $(5,6,41)$. As a consequence of decreased bile secretion, biliary elimination of many drugs and organic anions such as bilirubin may be impaired $(30,43,46)$ and the concentrations of bile acids reaching the intestine may be inadequate for optimal fat digestion (45). This immaturity of liver function may also place the infant at increased risk for clinical cholestasis as is commonly observed during gram negative infection or during parenteral nutrition $(2,8,18)$. It is our hypothesis that during development, efficient enterohepatic cycling of bile acids may, in part, be limited by immaturity of bile acid transport by the liver. We, therefore, sought maturational changes in the uptake of taurocholate by hepatocytes isolated from suckling and weanling rats.

\section{METHODS AND MATERIALS}

Animals. Suckling and weanling Sprague-Dawley rats were obtained from Charles River Breeding Laboratories and were housed in a temperature-controlled room at $22^{\circ} \mathrm{C}$ with alternating $12 \mathrm{~h}$ light-dark cycles. Mothers and weanlings were maintained on Purina rat chow and water ad libitum. Male rats were utilized for hepatocyte isolation and all studies were conducted at midday.

The chemicals used in this study were: tauro-[carbonyl $-{ }^{14} \mathrm{C}$ ] cholic acid, $(52.0 \mathrm{mCi} / \mathrm{mmoles}$; greater than $98 \%$ pure by thin layer chromatography) and $\left[{ }^{3} \mathrm{H}\right]$-inulin, $(1 \mathrm{mCi} / 6.9 \mathrm{mg})$ both from New England Nuclear Corp. (Boston, MA); collagenase (type II), Sigma Chemical Corp. (St. Louis, MO); sodium taurocholate (greater than $98 \%$ pure by thin layer chromatography) from Calbiochem (San Diego, CA); silicone oil, density, $1.05 \mathrm{~g} / \mathrm{ml}$, Aldrich Chemical Co, (Milwaukee, WI); trypan blue, 0.4\%, Gibco Laboratories, (Grand Island, NY); bovine serum albumin (fraction V) from Sigma Chemical Co. (St. Louis, MO); and Insta-Gel from Packard (Downers Grove, IL). All reagents used in the preparation of the buffers were commercially available and of analytical grade.

Hepatocyte Isolation. Hepatocytes were isolated by a recirculating perfusion technique in rats at 14,21, 28 and 56 days of age according to the method of Bissel et al. (9). Each rat liver was perfused in situ through the portal vein at a rate of approximately $2 \mathrm{ml} / \mathrm{g}$ of liver/min with oxygenated calcium-free Hank's buffer at $\mathrm{pH} 7.4$ and at $37^{\circ} \mathrm{C}$ for a total volume of $1 \mathrm{ml} / \mathrm{g}$ body weight and then for $25 \mathrm{~min}$ with a $0.05 \%$ solution of collagenase in the same buffer. In pups of 7 days of age, the liver was perfused retrograde through the thoracic portion of the inferior vena cava as described by Ziegler (47). After perfusion, the livers were removed, the tissue gently dispersed with scissors, and incubated for an additional $10 \mathrm{~min}$ in $25-50 \mathrm{ml}$ of $0.05 \%$ collagenase-buffer solution in a rotatory water bath at $37^{\circ} \mathrm{C}$. The resulting cell preparation was then filtered through two layers of cheese cloth, washed and separated three times by low speed centrifugation (50 $\times g$ for $2 \mathrm{~min}$ ) to yield a preparation of greater than $95 \%$ hepatocytes. The final cell pellet was resuspended in $10 \mathrm{ml}$ of buffer (137 mM NaCl, $5.2 \mathrm{mM} \mathrm{KCl}, 0.9 \mathrm{mM} \mathrm{MgSO}_{4} \cdot 7 \mathrm{H}_{2} \mathrm{O}, 0.12$ $\mathrm{mM} \mathrm{CaCl}_{2}, 10 \mathrm{mM} \mathrm{Na}_{2} \mathrm{HPO}_{4}, 25 \mathrm{mM} \mathrm{NaHCO}_{3}$, and $1 \%$ glucose) containing $2 \%$ bovine serum albumin. This concentration of albumin was the minimum necessary to maintain cell viability in suspension for a period of greater than $3 \mathrm{hr}$. The number and homogeneity of the isolated cells were estimated in a hemocytometer. Hepatocytes were diluted with buffer to a final concentration of $1.5 \times 10^{6}$ cells $/ \mathrm{ml}$ and maintained in a rotatory water bath at $37^{\circ} \mathrm{C}$ under $95 \% \mathrm{O}_{2} / 5 \% \mathrm{CO}_{2}$.

Freshly isolated hepatocytes from each age group were $90-95 \%$ viable as assayed by trypan blue exclusion before and at the completion of each experiment (32). Plasma membrane integrity was also suggested by minimal loss of intracellular enzyme activity into the incubation medium (rate of lactic acid dehydrogenase release less than $3 \%$ of intracellular activity per hour) (9). The rate of incorporation of $\left[{ }^{14} \mathrm{C}\right]$-leucine into cellular protein was linear in isolated hepatocytes (28).

Taurocholate uptake. After preincubation for $20 \mathrm{~min}$ at $37^{\circ} \mathrm{C}$ under $95 \% \mathrm{O}_{2} / 5 \% \mathrm{CO}_{2}, 2 \mathrm{ml}$ of the diluted cell suspension were added to a prewarmed vial containing $\left[{ }^{14} \mathrm{C}\right]$-taurocholate tracer $(90 \mathrm{nCi})$ and varying concentrations of unlabeled taurocholate $(5$, $10,25,50,100,200 \mu \mathrm{M})$. Tritiated inulin was included in the 
medium as a marker for adherent extracellular fluid. Two hundred $\mu \mathrm{l}$ aliquots were taken at $15,30,45$ and $60 \mathrm{sec}$ and placed into 0.5 $\mathrm{ml}$ microfuge tubes. In initial experiments, samples were obtained at 90 and $300 \mathrm{sec}$ to establish accurate data regarding the time course of uptake. Hepatocytes were immediately separated from the incubation medium by microfuge centrifugation $(10,000 \mathrm{Xg}$ for $5 \mathrm{sec})$ through a layer of silicone oil $(100 \mu \mathrm{l})$ into $3 \mathrm{M} \mathrm{KOH}$ $(50 \mu 1)(3,35,36,37)$. After dissolution of the cell pellet in the $\mathrm{KOH}(18-24 \mathrm{~h})$, the bottom of each microfuge tube was cut off at the silicone oil- $\mathrm{KOH}$ interface and placed in a scintillation vial. Seventy-five $\mu$ of $2 \mathrm{~N} \mathrm{HCl}$ and $10 \mathrm{ml}$ of Insta-Gel scintillation cocktail were added to each vial and mixed thoroughly. The dissolved cell pellets and a sample of the incubation medium were then subjected to radioassay for ${ }^{14} \mathrm{C}$ and ${ }^{3} \mathrm{H}$ content in a Beckman liquid scintillation spectrophotometer. No significant radioactivity appeared in the oil phase and $1 \%$ or less of the total ${ }^{3} \mathrm{H}$-inulin counts were associated with the sedimented cell fraction. Protein was determined according to the method of Lowry et al. (27). Results are expressed in nmoles of taurocholate per mg of cellular protein.

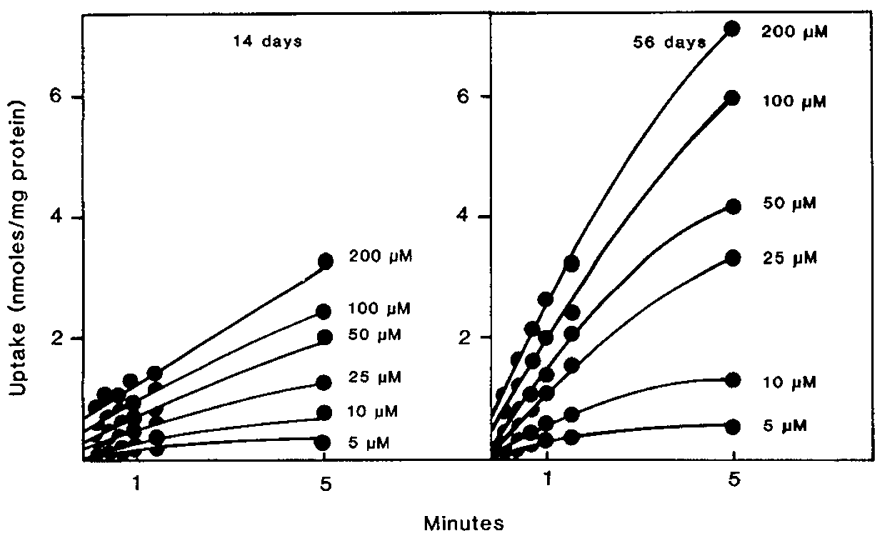

Fig. 1. Time course of taurocholate uptake by hepatocytes isolated from 14- and 56-day-old rats.
The $\mathrm{Km}$ and $\mathrm{Vmax}$ for taurocholate uptake in each experiment were derived from a double reciprocal plot of the initial uptake velocity versus taurocholate concentration according to Lineweaver-Burk (29). The kinetic values at each age were expressed as the mean \pm S.E. Student's $t$ test was used for statistical comparison.

\section{RESULTS}

Representative time courses for taurocholate uptake by hepatocytes isolated from 14- and from 56-day-old rats are shown in Figure 1. Uptake of taurocholate at concentrations from 5-200 $\mu \mathrm{M}$ was linear in excess of $90 \mathrm{sec}$, similar to data reported by other investigators using hepatocytes from adult rats $(4,35)$. Extrapolation of the uptake versus time plot yielded a positive intercept suggesting rapid initial adsorption of taurocholate to the plasma membrane. This adsorption apparently occurs independently from influx and has been observed with other amphiphilic compounds such as bromosulfophthalein (36) and estrone sulfate (38).

Initial rates of taurocholate uptake were subsequently calculated from the uptake during the first min of each experiment. On Figure 2 the initial uptake velocity (Vo) (nmoles $/ \mathrm{min} / \mathrm{mg}$ protein) is plotted as a function of taurocholate concentration. Each curve represents the mean and S.E. of six separate hepatocyte preparations from each age group. There was a progressive increase in taurocholate uptake by hepatocytes isolated from rats between 7 and 56 days of age. The uptake process was found to be saturable in each group with a maximum uptake velocity attained above a taurocholate concentration of $200 \mu \mathrm{M}$.

Rate constants were determined from a double reciprocal plot of each experiment and are shown graphically in Figure 3. Vmax increased with postnatal age. At 7 days the $V \max$ was only $23 \%$ of that attained in animals of 56 days of age $(P<0.001)$; the $V \max$ at this time was also significantly reduced in comparison to rats studied on day 21 and $28(P<0.01)$ but did not differ from that of the 14-day-old pups. The maximum velocities on days 14 , 21 and 28 remained significantly less than the 56-day-old rats ( $P$ $<0.01)$. A 2 -fold increment in Vmax occurred between weaning (21 days) and 56 days. In contrast there were no significant

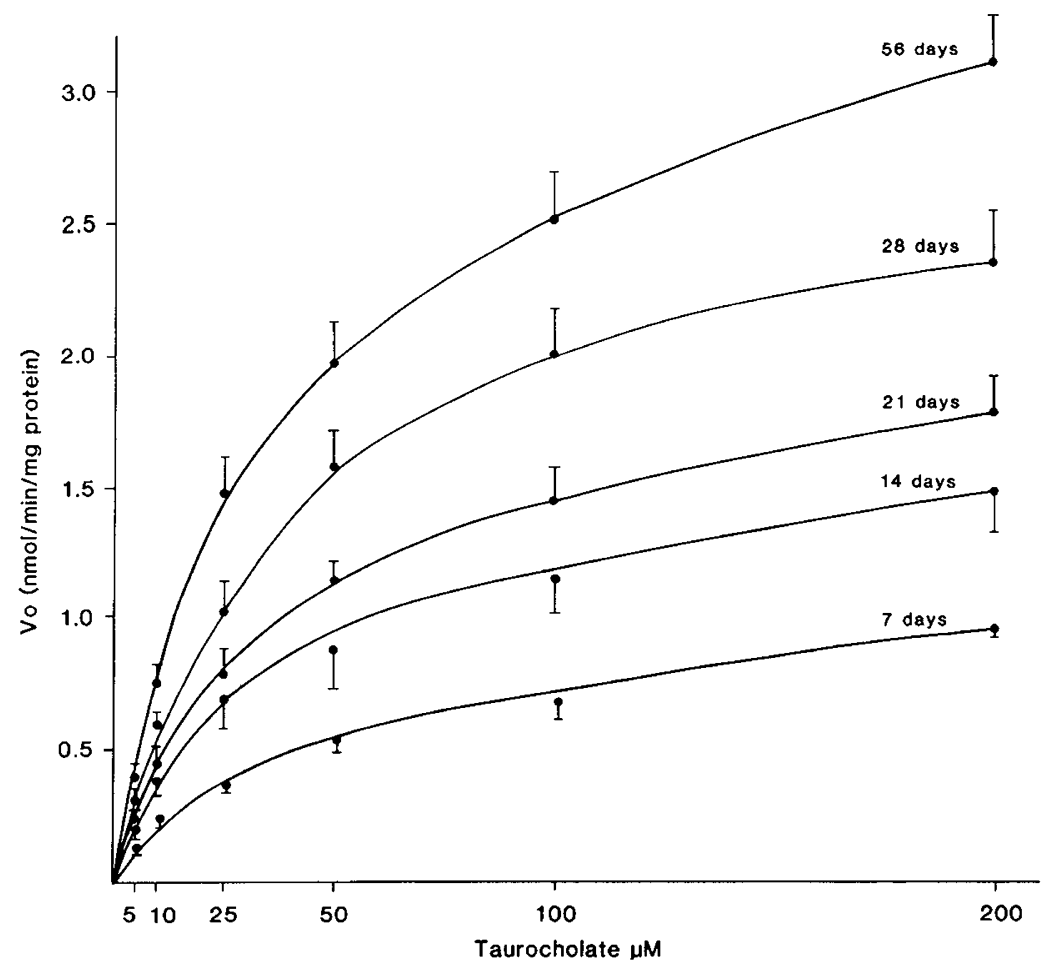

Fig. 2. Initial velocity of taurocholate uptake (Vo) plotted against substrate concentration for hepatocytes isolated from developing rats.

Each point represents the mean \pm S.E. of data obtained from six animals. 

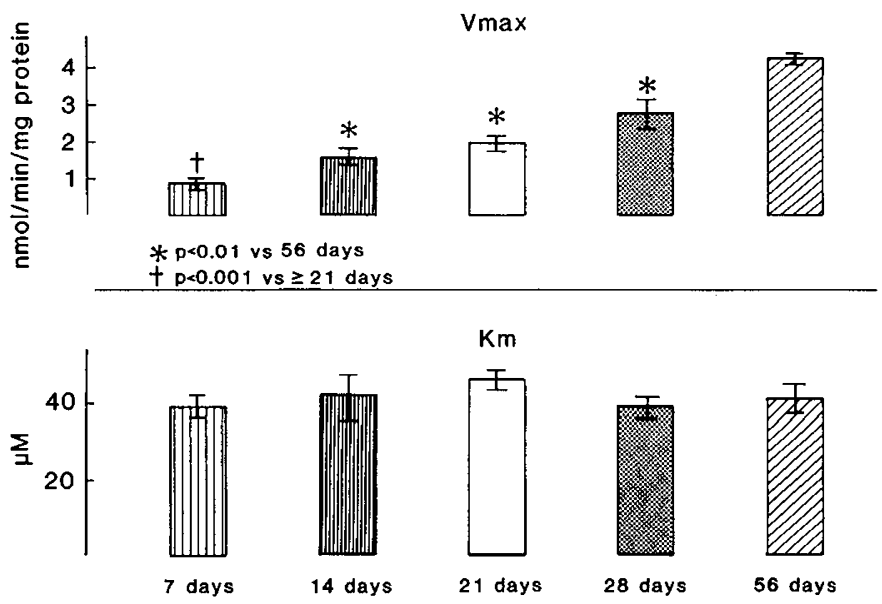

Fig. 3. Rate constants for uptake of taurocholate by hepatocytes isolated from developing rats. Each bar represents the mean \pm S.E. of data obtained from six animals.

differences in $\mathrm{Km}$ values for taurocholate uptake for any of the age groups studied.

\section{DISCUSSION}

Studies performed in the isolated perfused rat liver and in isolated hepatocytes indicate that bile acid uptake is an active, sodium-dependent process $(4,33)$. The initial interaction between bile acids and the liver cell occurs at the sinusoidal face of the surface membrane where a putative bile acid receptor has been identified (1). A Na ${ }^{+} \mathrm{K}^{+}$ATPase has been localized to the basolateral portion of the hepatocyte and maintains a low intracellular sodium concentration by pumping sodium out of the cell in exchange for potassium (10). It is hypothesized that the sodium gradient that is created drives a sodium-anion coupled carrier that enables coupled anions such as bile acids to accumulate within the hepatocyte against an electrochemical gradient (11). Subsequent intracellular and canalicular transport is poorly understood but bile acids may be extruded into bile by active transport or in response to an electrochemical gradient (11).

The maturation of bile acid transport by the immature liver has not been directly examined. The use of an isolated hepatocyte system allows the study of functions specific to this cell type without the variability of blood flow and the interference of supporting tissue. Our data has demonstrated age-related changes in the uptake of taurocholate, the primary conjugated bile acid of the rat and of the human infant, in hepatocytes isolated from suckling and weanling rats. The uptake process was saturable and increased progressively between 7 and 56 days of age. $\mathrm{Km}$ values for taurocholate transport did not change appreciably with postnatal age, suggesting that the affinity of the liver cell plasma membrane for taurocholate remains constant during this period. However, the 4-fold increase in Vmax may reflect an increase in the number of transport or binding sites. The rate constants derived in 56-day-old rats are similar to those reported by other authors for the mature rat, e.g., a $\mathrm{Km}$ of $20-40 \mu \mathrm{M}$ and a Vmax of $1.8-3.8 \mathrm{nmoles} / \mathrm{min} / \mathrm{mg}$ protein $(4,31,35)$. Stacey and Klaassen (40) have observed a similar pattern of development for ouabain uptake in isolated rat hepatocytes; Vmax increased gradually with postnatal age whereas $\mathrm{Km}$ values remained constant.

Impaired hepatic transport of bile acids is supported by the finding of elevated concentrations of cholylglycine and conjugates of chenodeoxycholate in the serum of normal infants during the first months of life $(5,41)$. Similarly, serum concentrations of total cholate conjugates were markedly elevated in the serum of suckling and weanling rats (6). An exaggerated postprandial rise in the serum bile acid concentration in infants may reflect defective uptake by the liver, a finding that is especially striking in light of the probable inefficiency of intestinal bile acid reabsorption in the first months of life, which would tend to blunt the serum response (41). Studies in fetal dogs (19), monkeys (25), sheep (39), and in rat pups (24) have also shown delayed clearance of labeled taurocholate from serum. Decreased excretion of other organic anions by the developing liver may not only indicate immaturity of carrier mechanisms specific to these compounds but may also be related to impaired bile secretion. It has been suggested that concentrative transport of a variety of drugs and organic anions into bile may result from their incorporation into mixed micelles would be directly influenced by the availability of bile acids within the canalicular lumen (34).

The ontogeny of taurocholate uptake by the liver may be examined in the context of other developmental changes in the enterohepatic circulation of bile acids. Although uptake was a saturable process in hepatocytes isolated from rat pups even at 7 days of age, active ileal transport of bile acids was not demonstrated in two recent studies until after the second wk of life (26, 42). The rapid increase in bile acid pool size and the enhanced intestinal conservation of bile acids around the time of weaning may overwhelm the capacity of the developing liver to clear bile acids from the portal blood $(26,42)$. Bile acids would then spill over into peripheral blood as occurs during liver disease. Maximally elevated serum cholic acid levels are in fact detected in developing rats at 21-28 days and can be related to this increased bile acid load in the face of impaired transport by the liver (6). Progressive maturation of liver function possibly including uptake, intracellular binding, conjugation and secretion of bile acids leads to eventual "normalization" of serum bile acids in the rat during the second month of life (6).

The factors modulating the development of taurocholate uptake by the liver are unknown. The surges in plasma thyroxine and corticosterone known to occur during the mid-suckling period are likely to effect clusters of enzymes including those involved in hepatic lipid metabolism and in the biosynthesis of membranes $(16,17)$. The final steps of biochemical and structural differentiation in the liver may, in part, be related to the major change in diet associated with weaning (23). Since a $\mathrm{Na}^{+} \mathrm{K}^{+}$ATPase and a proposed bile acid receptor have been localized to the liver plasma membrane, the organization of this membrane in particular should play a key role in the maturation of bile acid transport $(1,3 ; 10)$. The influence of the lipid composition and fluidity of a membrane system on membrane transport, enzyme activity, and on ligandreceptor interactions have been demonstrated in many studies involving liver and other tissues $(7,12,21,22)$.

\section{REFERENCES AND NOTES}

1. Accatino, L. and Simon, F. R.: Identification and characterization of a bile acid receptor in isolated liver surface membrane. J. Clin. Invest., 57: 496 (1976).

2. Andres, J. M., Mathis, R. K., and Walker, W. A.: Liver disease in infants. I Developmental hepatology and mechanisms of liver dysfunction. J. Pediatr., 90: 686 (1977).

3. Anwer, M. S., Kroker, R., and Hegner, D.: Cholic acid uptake into isolated rat hepatocytes. Hoppe-Seyler's Z. Physiol. Chem., 357: 1474 (1976).

4. Anwer, M. S. and Hegner, D.: Effect of $\mathrm{Na}^{+}$on bile acid uptake by isolated rat hepatocytes. Hoppe-Seyler's Z. Physiol. Chem., 359: 181 (1978).

5. Barbara, L., Lazzari, R., Roda, A., Aldini, D., Festi, D., Sama, C., Collina, F., Bazzoli, F., Mazzella, G., and Roda, E.: Serum bile acids in newborns and children. Pediatr. Res., 14: 1222 (1980).

6. Belknap, W. M., Balistreri, W. F., Suchy, F.J., and Miller, P.: Physiologic cholestasis. II: Serum bile acids reflect the development of the enterohepatic circulation in rats. Hepatology $1: 613$ (1981).

7. Benz, R., Frohlich, O., . $\therefore$ Lauger, P.: Influence of membrane structure on the kinetics of carrier-media $=d$ ion transport through lipid bilayers. Biochim. Biophys. Acta, 464: 465 (1977).

8. Bernstein, J., Chang, C. H., Brough, A. J., and Heidelberger, K. P.: Conjugated hyperbilirubinemia in infancy associated with parenteral nutrition. J. Pediatr., 90: 361 (1977).

9. Bissell, D. M., Hammaker, L. E., and Meyer, V. A.: Parenchymal cells from adult rat liver in a nonproliferative monolayer culture. I. Functional studies. J. Cell. Biol., 59: 722 (1973).

10. Blitzer, B. L. and Boyer, J. L.: Cytochemical localization of $\mathrm{Na}^{+} \mathrm{K}^{+}$ATPase in the rat hepatocyte. J. Clin. Invest., 62: 1104 (1978).

11. Boyer, J. L.: New concepts of mechanisms of hepatocyte bile formation. Physiol. Rev., 60: 303 (1980)

12. Davis, R. A., Kern, F., Showwalter, R., Sutherland. E., Sinensky, M., and Simon, F. R.: Alterations of hepatic $\mathrm{Na}^{+} \mathrm{K}^{+}$ATPase and bile flow by estrogens: effects 
on liver surface membrane lipid structure and function. Proc. Natl. Acad. Sci., 75: 4130 (1978).

13. DeWolf-Peeters, C., DeVos, R., and Desmet, V.: Histochemical evidence of a cholestatic period in neonatal rats. Pediatr. Res., 5: 704 (1971).

14. DeWolf-Peeters, D., DeVos, R., and Desmet, V.: Electron microscopy and morphometry of canalicular differentiation in fetal and neonatal rat liver. Exp. Molec. Path., 2l: 339 (1974).

15. Forker, E. L.: Mechanisms of hepatic bile formation. Ann. Rev. Physiol., 39: 323 (1977)

16. Goldsmith, P. K.: Postnatal development of some membrane-bound enzymes of rat liver and kidney. Biochim. Biophys. Acta, 672: 45 (1981).

17. Greengard, O.: The developmental formation of enzymes in the rat liver. IN Biochemical Actions of Hormones, Vol. I. Litwach, G. (ed.). pp 53-87 (Academic Press, New York, NY 1970).

18. Hamilton, J. R. and Sass-Kortsak, A.: Jaundice associated with severe bacterial infection in young infants. J. Pediatr., 63: 121 (1963).

19. Jackson, B. T., Smallwood, R. A., Piasecki, G. J., Brown, A. S., Rauschecker, M F., and Lester, R.: Fetal bile salt metabolism. I. The metabolism of sodium cholate- $\left[{ }^{14} \mathrm{C}\right]$ in the fetal dog. J. Clin. Invest., 50: 1286 (1971).

20. Jones, R. S., Meyers, W. C.: Regulation of hepatic biliary secretion. Ann. Rev. Physiol., 41: 67 (1979).

21. Keeffe, E. B., Scharschmidt, B. F., Blankenship, N. M., and Ockner, R. K. Studies of relationships among bile flow, liver plasma membrane, $\mathrm{Na}^{+} \mathrm{K}^{+}$ ATPase and membrane microviscosity in the rat. J. Clin. Invest., 64: 1590 (1979).

22. Kimelberg, $\mathrm{K}$.: Alterations in phospholipid-dependent $\left(\mathrm{Na}^{+} \mathrm{K}^{+}\right)$-ATPase activity due to lipid fluidity. Biochim Biophys Acta, 413: 143 (1975).

23. King, M. E., Stavens, P. W., and Spector, A. A.: Diet-induced changes in plasma membrane fatty acid composition affect the physical properties detected with a spin-label probe. Biochemistry, 16: 5284 (1977)

24. Klaassen, C. D.: Independence of bile acid and ouabain hepatic uptake: Studies in the newborn rat. Proc. Soc. Exp. Biol. Med., 157: 66 (1978).

25. Little, J. M., Smallwood, R. A., Lester, R., Piasecki, G. J., and Jackson, B. T.: Bile-salt metabolism in the primate fetus. Gastroenterology, 69: 1315 (1975).

26. Little, J. A. and Lester, R.: Ontogenesis of intestinal bile salt absorption in the neonatal rat. Am. J. Physiol., 239: G319 (1980).

27. Lowry, O. H., Rosenbrough, N. F., Fan, A. L., and Randall, R. J.: Protein measurement with the folin reagent. J. Biol. Chem., 193: 265 (1951).

28. Mans, R. J. and Novelli, G. D.: Measurement of the incorporation of radioactive amino acids into protein by a filter-paper disk method. Arch. Biochem. Biophys., 94: 48 (1961).

29. Michal, G.: Determination of Michaelis constants and inhibitor constants. In Principles of Enzymatic Analysis. Bergmeyer, H. (Ed.) B29-39 (New York, Verlag Chemie, 1978).

30. Odell, G. B.: Neonatal jaundice. In: Progress in Liver Diseases. Vol. V, Popper, H. and Schaffner, F. (Ed.) pp 457-475, (Grune and Stratton, New York, NY 1976).

31. Olinger, E. J., Hercker, E. S. and Ostrow, J. D.: Hormonal modulation of taurocholate transport by isolated hepatocytes: effects of secretin and cholecystokinin. Clin. Res., 26: 324A (1978).
32. Philips, M. J.: Dye exclusion tests for cell viability. In: Tissue culture. Methods and Application. Kruse, P. F. and Patterson, M. K. (Ed.), pp. 406-408 (Academic Press, New York NY 1973).

33. Reichen, J. and Paumgartner, G.: Uptake of bile acids by the perfused rat liver. Am. J. Physiol., 23I: 734 (1976).

34. Scharschmidt, B. F. and Schmid, R.: The micellar sink. A quantitative assessment of the association of organic anions with mixed micelles and other macromolecular aggregates in the rat bile. J. Clin. Invest., 62: 1122 (1978).

35. Schwarz, L. R., Burr, R., Schwenk, M., Pfaff, E., and Greim, H.: Uptake of taurocholic acid into isolated rat-liver cells. Eur. J. Biochem., 55: 617 (1975).

36. Schwenk, M., Burr, R., Schwarz, L., and Pfaff, E.: Uptake of bromosulfophthalein by isolated liver cells. Eur. J. Biochem., 64: 189 (1976).

37. Schwenk, M.: Transport systems of isolated hepatocytes. Arch. Toxicol., 44: 113 (1980).

38. Schwenk, M. and Lopez del Pino. V.: Uptake of estrone sulfate by isolated rat liver cells. J. Steroid Biochem., 13: 669 (1980).

39. Sewell, R. B., Hardy, R. J., Smallwood, R. A. and Hoffman, N. E.: The hepatic transport of sodium $-\left[{ }^{14} \mathrm{C}\right]$-taurocholate in foetal sheep. Clin. Exp. Pharmacol. Physiol., 6: 117 (1979)

40. Stacey, N. and Klaassen, C. D.: Uptake of ouabain by isolated hepatocytes from the livers of developing rats. J. Pharmacol. Exp. Ther., 211: 360 (1979).

41. Suchy, F. J., Balistreri, W. F., Heubi, J. E., Searcy, J. E. and Levin, R. S.: Physiologic cholestasis: elevation of the primary serum bile acids in normal infants. Gastroenterology, 80: 1037, 1981.

42. Suchy, F. J., Heubi, J. E., and Balistreri, W. F.: The enterohepatic circulation of bile acids in suckling and weanling rats. Gastroenterology, 80: 135A, 1981.

43. Vest, M. F.: Conjugation of sulfobromphthalein in newborn infants and children. J. Clin. Invest., 41: 1013 (1962).

44. Watkins, J.B., Ingall, D., Szczepanik, P., Klein, P. D., and Lester, R.: Bile-salt metabolism in the newborn. N. Engl. J. Med., 288: 431 (1973).

45. Watkins, J. B., Lester, R., Bliss, C. M., and Donaldson, R. M.: Characterization of newborn fecal lipid. Pediatrics, 53: 511 (1974).

46. Yudkin, S. and Gellis, S.: Liver function of newborn infants with special reference to excretion of bromsulphalein. Arch. Dis. Child., 24: 12 (1949).

47. Ziegler, K.: Isolation of hepatocytes from newborn rats. Arch. Toxicol., 44: 99 (1980).

48. This paper was presented in part at the Annual Meeting of the American Association for the Study of Liver Diseases in Chicago, IL on November 7, 1980 and has been published in abstract form (Gastroenterology, 79: 1056 1980).

49. Requests for reprints should be addressed to: Dr. Frederick J. Suchy, Division of Gastroenterology, Children's Hospital Research Foundation, Cincinnati, $\mathrm{OH}$ 45229.

50. This research was supported in part by a Lipids-Atherosclerosis-Nutrition Training Program Grant (HL 07460) by the National Heart, Lung and Blood Institute and by the U.S. Public Health Service Grant (RR-00123) from the General Clinical Research Centers Branch, NIH. Dr. Suchy is a recipient of a Fellowship from the American Liver Foundation.

51. Received for publication March 12, 1981.

52. Accepted for publication August 20, 1981 